\title{
Ingen kjenner morgendagen
}

\author{
I november 2009 ble jeg rammet av hjerneblødning. Det skjedde plutselig og var dramatisk. Jeg kom imidler- \\ tid raskt til behandling, og ting har utviklet seg utrolig positivt. Jeg er nå klar for å fortsette der jeg slapp, \\ som lærer, ektefelle og mor. Men ikke helt som før. For dette har gjort noe med meg.
}

\section{Lørdag kveld.}

Legger meg etter en travel dag. Har ryddet og støvsuget huset. Tanken er å vaske dagen etter - godt å ikke gjøre alle operasjonene samme dag...Lager pizza til kvelds. Alltid stas med hjemmelaget pizzamer mat i den. Ellers klesvask og andre vanlige gjøremål. Avsluttet studentperiode fredag, og har en rapport igjen å skrive. Planen å få gjort det søndag. Med andre ord en ganske ordinær lørdag avsluttes med et glass vin ved kjøkkenbordet før søvnen innhenter meg raskt og barmhjertig...

\section{Noe skjer}

Jeg strever for å få opp øyelokkene og feste blikket. Mennesker og stemmer rundt meg. Fremmed rom, fremmed seng, skimter noen ved sengekanten. Vet etter hvert at jeg har hatt hjerneblødning. Vet ikke når eller hvordan jeg får vite det. Men husker at jeg konstaterer at det er det som har skjedd. Ja vel.

Får også vite at det ble ringt etter ambulanse omtrent før jeg besvimte. Hadde stått opp, dusjet og blitt kvalm og svimmel i dusjen. Kommenterte selv: «Jeg tror det er alvorlig.» Kastet kraftig opp og besvimte. Ambulanse kom i løpet av ti minutter. Ambulansehelikopter kom med nødvendig utstyr. Jeg ble stabilisert og kjørt av gårde i stor fart. Ungene var igjen alene hjemme kan mamma dø? Mormor og tante kom og var sammen med dem resten av dagen...

Ser meg selv i speilet og ser at hodet er barbert langs høyre side og på toppen. Registrerer at sånn er det. Ja vel. Ser at kroppen min er tynn. Tatt av mange kilo. Ja vel. Ser mann og barn i korte glimt ved sengekanten. Mor, far og søster. Besøk. Ja vel.

De forteller meg om ting de har gjort, julegaver som er kjøpt, planer de har lagt. De kommer og går. Jeg hører og konstaterer. Klarer ikke å ta inn over meg. Klarer ikke å bli engasjert.

For noe har skjedd. Noe er totalt snudd på hodet. Jeg er helt ute av stand til å kontrollere dette. Jeg bare er med, for dette involverer meg i alle høyeste grad, dette er tilværelsen min nå og jeg aksepterer det visstnok inntil videre med den største selvfølgelighet...
Begynner å bevege meg ute i gangen. Et fast grep på rullatoren. Går ut av døren subber langsomt bortover. Pleiere og besøkende haster forbi. Rask gange med største selvfølgelighet.

... Det går opp for meg at veien tilbake igjen ikke er like enkel. Har ikke registrert hvilket rom jeg forlot. Hvilket nummer. Noe kjennetegn? Må spørre om hjelp. Neste gang vet jeg at det er døren ved pepperkakehuset. Lettere å huske det enn nummeret.

Noe har også skjedd med synet mitt. Jeg ser dobbelt. Det ene øyet skjeler og det er veldig ubehagelig å bruke begge øynene. Ikke kan jeg bruke linser heller. Løsningen foreløpig blir lapp på venstre øye. Ser ikke mye friskere ut med den... Er til kontroll hos øyelege på Haukeland. Får vite at jeg har vært der før - i begynnelsen av desember. Husker ingenting av det. Får bekreftet at synet sannsynligvis vil bli som før. Ta tiden til hjelp, få tilpasset prismer på brilleglassene, så blir det lettere å se og lese.

\section{Julen nærmer seg}

Jeg merker selv at jeg blir mer til stede. Ting blir klarere, ikke fullt så kaotisk i toppen. Skal hjem en helg før jul for å se hvordan jeg fungerer der. Ser frem til det. Merker behovet for å bli den jeg var.

Det er opptur å snakke med venner og familie, få meldinger, føle at jeg fremdeles hører til i verden. I det livet som finnes utenfor veggene. Der jeg egentlig hører hjemme...

Når jeg er alene kommer tankene snikende. De står i kø. Skaper usikkerhet. Utrygghet. Den ene tanken mer dyster enn den andre. Og jeg vil ikke la dem få spillerom. Jeg vil være frisk - være med. Og tankene innbefatter ikke bare meg etter hvert. Også mine nærmeste. Hva som kan skje med dem... vi vet jo ikke... Det viser seg at dette skal henge i lenge. Så snart jeg har lagt meg, idet jeg er i ferd med å våkne, alene på dagtid. Det slår ikke feil. De er der. Parat til å trenge seg på. Gir meg ikke fred.

Alle er så omsorgsfulle, bryr seg, spør, vil hjelpe til. Ikke slik de ville vært om jeg var frisk, regnet med meg, stilt krav, forventet... Jeg vet det må være sånn. Jeg er pasient. Jeg har vært alvorlig syk. Jeg skal bli bedre. Det er det vi venter på.

Men jeg må også leve dagen i dag. $\mathrm{Og}$ i morgen. Og dagen deretter. Og ukene og månedene deretter. Før jeg er helt frisk. Og det er livet mitt nå. Kan ikke bare være på vent. Hjelp meg å gjøre dette meningsfylt!

Livet som var før. Når jeg er effektiv, ektefelle, mamma, lærer. Alltid full fart, ansvar, ting som må gjøres, kjøre, handle, hus, ikke tid til å bli syk, ta pause.

Så blir jeg bare kastet ut - settes på sidelinjen, lever en tilværelse totalt på sidelinjen. Og livet går faktisk videre, familien klarer seg godt, dyktige vikarer settes inn på jobb, de rundt meg er blide og fornøyde, de er på jobb, kommer tidlig, ser til oss, utfører sine oppgaver og kan gå hjem igjen - for så å komme på jobb igjen neste dag - de må jo vite hvor heldige de er - de må sette pris på hver dag de er friske og klare... og her er jeg... hallo, ikke glem meg, se meg, jeg vil være viktig, høre til! Jeg er ikke bare en pasient - jeg har aldri vært pasient før, dette er skremmende, fremmed, det er ikke meg!

Fra å støtte meg tungt til rullatoren kan jeg etter hvert ha et lettere grep på den. Et steg nærmere normalen, tegn på at ting er på rett vei... Men det er vanskelig å se til siden. Må stoppe opp dersom jeg skal det, og langsomt vende hodet til siden. Det skal henge $\mathrm{i}$ lenge.

Er hjemme en helg før jul for å se hvordan det fungerer. Og det går i grunnen bra. Må hvile en del. Tilbringer tid på sofaen og i sengen. Sover. Men er hjemme. Maten smaker bedre, selv om det tar tid å få den ned. Ser at ungene setter pris på å ha meg der.

Men ser også at de er blitt vant til å ikke ha meg der. De har sitt liv og lever sine dager med sitt innhold. Det er pappa de henvender seg til nå, pappa de spør om hjelp, pappa som må vite hvor regntøyet er og om vi har mer hvitost. Mamma er der og samtidig er hun der ikke. De er omsorgsfulle og tar hensyn. Og jeg synes det er helt greit. Ikke opprørt over det som skjer. Vet at de har det godt, at det er sånn det må være nå.

Men det er også godt å se. Godt å se at de klarer seg så bra. Søndag kan jeg reise opp igjen uten å være bekymret. For jeg ser at dette går. Jeg ser at jeg har en mann som 


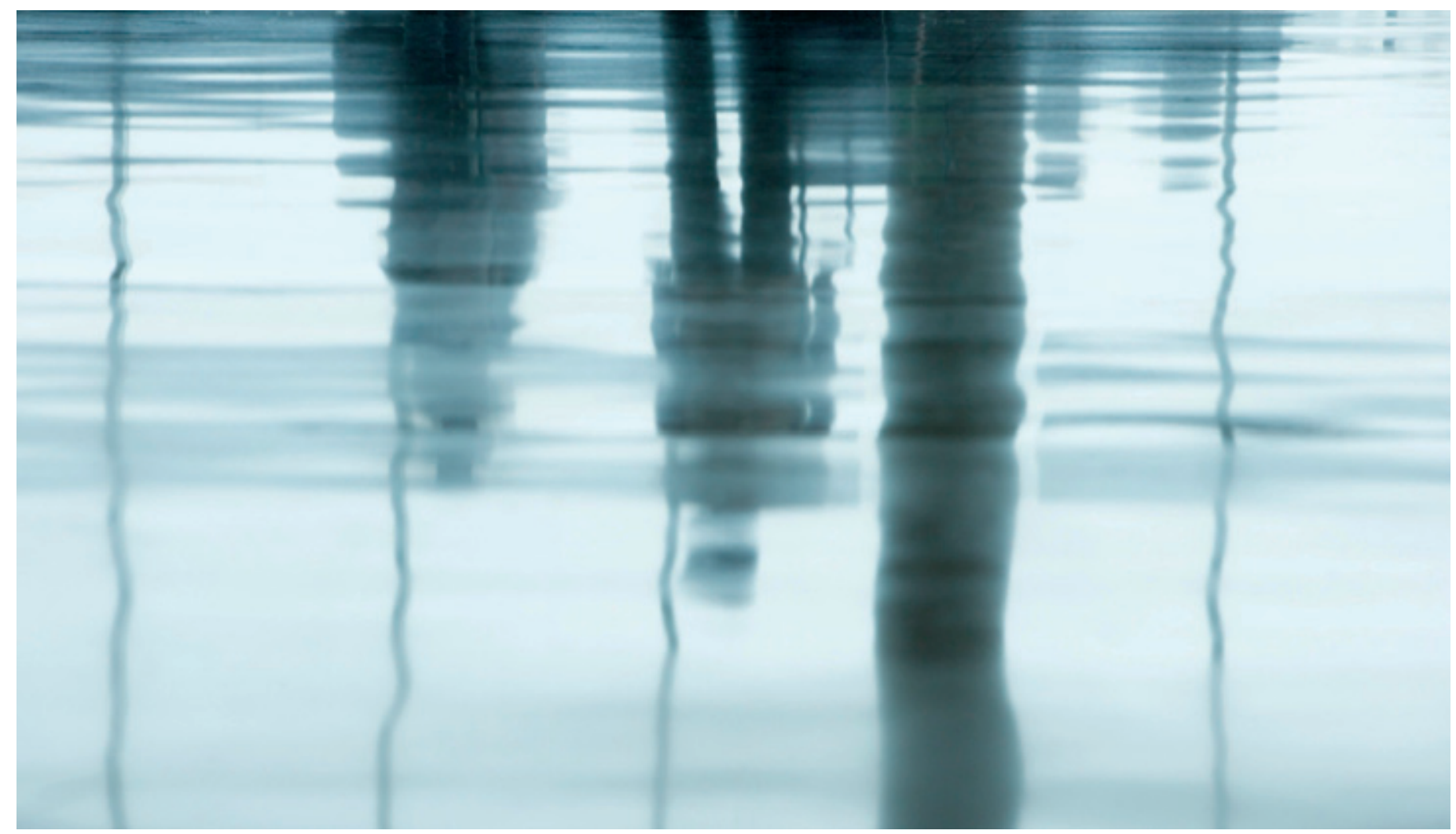

Illustrasjonsfoto Colourbox

takler dette veldig bra. Som har tatt ungene med på laget siden starten. De har vært sammen om dette. Og derfor går det også. Derfor tilpasser de seg så bra - tilpasser hverdagen sin slik den må være.

Hjemme må ungene være med. De deler ansvar, alle må hjelpe til med å ta sin del. Og det gjør de. Med den største selvfølgelighet dekker de bord og rydder opp, bretter sammen klær og legger dem på plass.

Jeg vet at hadde jeg vært alene under samme forhold, hadde jeg vært utslitt av å skulle utføre alt på egenhånd - helst i enda større grad enn vanlig, bare for å vise at dette takler jeg - omgivelsene må se at dette går bra...

\section{Jul}

Kommer hjem lille julaften. Vinteren er stabil. Snø og kulde. Må kle meg godt når vi kjører fra sykehuset. Det skjer heller ikke som før. Jeg ville normalt aldri tatt på meg oransje strikkelue og blå polvotter til dunkåpe. Men det gjør jeg. Det er det jeg finner og det varmer. Og det holder. Nå gjør det det.

Jeg kjøres til foreldrene mine for å være der til kvelden. Mann og barn skal til svigermor som vanlig denne dagen. Ikke aktuelt for meg $\mathrm{i}$ år.

\section{Julaften}

Som vanlig forventning og spenning. God mat. Pynt. Gaver. Og jeg er gjest. Sover. Spiser. Vandrer litt rundt. Hviler. Pinnekjøtt som vanlig. Litt spiser jeg. Gaveutdeling.
Jeg får mye toalettartikler - sjampo og gode kremer. Fotoapparat fra familien. Som blir raskt overtatt av ivrige hender. Det er helt greit. Nyttårshelgen er jeg også hjemme. Fremdeles som gjest...

\section{Rehabilitering}

På nyåret får jeg plass på rehabiliteringssenter. Der skal jeg være mandag til fredag, og hjem på perm $\mathrm{i}$ helgene.

Etter hvert begynner jeg nå å få et forhold til meg selv og den jeg er. Hukommelsen er bedre, tilstanden i toppen har roet seg betraktelig. Og dette oppleves som et veldig bra sted å være akkurat nå. Et team av profesjonelle rundt meg. Som er opptatt av meg, av at jeg skal ha fremgang, som har tid til å snakke med meg og hjelpe meg, som bryr seg på en oppriktig måte.

Jeg skriver dagbok - i første rekke som en hjelp til å huske. Etter hvert også en fin måte å få bearbeidet følelser og inntrykk på.

Trening. Hver dag. Med fysioterapeut og ergoterapeut. Det er veldig godt bare å få snakket med dem også. Igjen opplever jeg meg selv som mer frisk gjennom samtalene. For jeg har noe å bidra med - kan gjøre samtalene meningsfulle. Får tilbakemelding på det. Og det gjør godt!

Gjennomfører mental trening med psykolog. Det liker jeg. Det trigger meg. Her vil jeg vise at jeg fremdeles kan! Være konsentrert, finne løsninger, se mønster, huske. Jeg blir irritert når jeg ikke får til.

Helgene hjemme blir mer meningsfulle. Jeg kan utrette mer. Blir mer opptatt av og engasjert i ting. Og opplever sterkere ønsket om og behovet for å stadig bli friskere. Det går fremover.

\section{Hjemme igjen}

Etter fem uker er jeg hjemme. For godt. Klar for trening på lokalt institutt. Klar for å være ektefelle og mamma. Klar for å fortsette der jeg slapp. Men ikke helt som før. For dette har gjort noe med meg. Jeg har fått en dyrekjøpt erfaring. Jeg har fått en innsikt jeg på en måte gjerne skulle vært foruten.

Likevel, etter å ha fått oppleve at jeg blir helt frisk igjen, ser jeg at dette har gitt meg noe. Og lært meg noe. Lært meg noe om sårbarhet. Gitt meg et ørlite glimt av det korte spennet mellom liv og død. Vist meg at ingenting er gitt. Ingenting er en selvfølge.

«Ingen kjenner morgendagen» er en flittig brukt vending. For meg fikk den et brutalt innhold. Som også har gitt meg ny kunnskap. Kunnskap om meg selv. På ulike felt. Kunnskap som har utviklet meg som menneske og gitt meg lærdom for livet.

\section{Elisabeth Mohn Danielsen}

eldani@online.no

Breisteinvegen 309

5111 Breistein

Manuskriptet ble mottatt 18.6. 2010 og godkjent 1.7. 2010. Medisinsk redaktør Erlend Hem. 